\title{
Parent-Infant Psychotherapy and Postpartum Depression: The Father's Participation
}

\author{
Milena da Rosa Silva ${ }^{1}$ \\ Universidade Federal do Rio Grande do Sul, Porto Alegre-RS, Brazil \\ Luiz Carlos Prado \\ Instituto da Família de Porto Alegre, Porto Alegre-RS, Brazil \\ Cesar Augusto Piccinini \\ Universidade Federal do Rio Grande do Sul, Porto Alegre-RS, Brazil
}

\begin{abstract}
Given the specificities of postpartum maternal depression, the literature recommends that fathers become involved in psychological interventions within this context. This study presents an investigation of the participation of fathers in parentinfant psychotherapy in the context of maternal postpartum depression. Two families participated in this study, both with a child aged between 7 and 8 months old, whose mothers showed depressive symptoms. These families participated in parentinfant psychotherapy lasting approximately 12 sessions. Analysis of the fathers' participation in psychotherapy showed that their presence during sessions enables the therapy to address aspects of parenthood, and also reduce the feeling of mothers as being the only ones responsible for the family's process of change. In regard to the technique, the presence of fathers during sessions allows the therapist to see and address the issues concerning mother-father-infant during sessions.
\end{abstract}

Keywords: fatherhood, postpartum depression, psychotherapy

\section{Psicoterapia Pais-Bebê e Depressão Pós-Parto Materna: Participação do Pai}

\begin{abstract}
Resumo: Em função das especificidades da depressão pós-parto materna, a literatura recomenda a participação do pai em intervenções psicológicas nesse contexto. Este estudo buscou investigar a participação do pai na psicoterapia breve pais-bebê no contexto de depressão pós-parto materna. Participaram duas famílias com um bebê com idade entre 7 e 8 meses, cujas mães apresentavam indicadores de depressão. Estas famílias participaram de uma psicoterapia pais-bebê de aproximadamente 12 sessões. A análise do modo como os pais participaram da psicoterapia mostrou que sua presença na sessão permite que sejam trabalhados com ele aspectos relativos à paternidade, além de diminuir a sensação da mãe de ser a única responsável pelo processo de mudança da família. Em relação à técnica, a presença do pai na sessão permite ao terapeuta visualizar as dificuldades da tríade no tratamento, as quais podem ser trabalhadas na sessão.
\end{abstract}

Palavras-chave: paternidade, depressão pós-parto, psicoterapia

\section{Psicoterapia Padres-Bebé y Depresión Puerperal: Participación del Padre}

\begin{abstract}
Resumen: Dadas las características específicas de la depresión postparto, la literatura recomienda que los padres participen en las intervenciones psicológicas en este contexto. Este estudio tuvo como objetivo examinar la participación de los padres en la psicoterapia breve padre-bebé en el contexto de la depresión postparto materna. Dos familias participaron en este estudio, con niños de 7 a 8 meses, cuyas madres presentaron síntomas de depresión. Estas familias participaron en una psicoterapia padres-bebé de aproximadamente 12 sesiones. El análisis de cómo los padres participaron en la psicoterapia demostró que su presencia en la sesión permite el trabajo con aspectos de la paternidad. También disminuye la sensación de la madre de ser la única responsable por el proceso de cambio de la familia. En cuanto a la técnica, la presencia del padre en la sesión permite al terapeuta ver las dificultades en el tratamiento de la tríada, que se puede trabajar en la sesión.
\end{abstract}

Palabras clave: paternidad, depresión postparto, psicoterapia

The figure of the father and its importance for child development, especially in the first years of a child's life, are themes seldom explored by psychology until recently. In the last three decades, however, as a result of social issues that substantially changed the context in which children are raised, an increased interest has been observed in studies addressing fatherhood (Cabrera, Tamis-LeMonda, Bradley, Hofferth, \& Lamb, 2000).

\footnotetext{
${ }^{1}$ Correspondence address:

Milena da Rosa Silva. Universidade Federal do Rio Grande do Sul. Rua Ramiro Barcelos, 2600, sala 130. CEP 90350-003. Porto Alegre-RS, Brazil. E-mail: milenarsilva@hotmail.com
}

Studies published in recent decades addressing fatherhood mainly focus on the role of fathers concerning childcare, how fathers behave with their children, and what are the effects of such behavior and presence, or absence, of the father on the child's development (Silva \& Piccinini, 2007). Scientific discourse and current demands toward fathers tend to require from them skills and performance as if they were mere simulacrums of mothers, limiting the understanding of potential specificities of fatherhood in relation to motherhood (Bornholdt, 2006; Guerra, 2004; Piccinini, Gonçalves, Guimarães, Silva, \& Lopes, 2013; Silva \& Piccinini, 2012). Considering the importance of understanding how parents are currently experiencing fatherhood and configuring new fathermother-infant relationships, it is essential to investigate how 
fathers participate in psychotherapy treatments focusing on these relationships.

\section{Fatherhood and Parent-Infant Psychotherapy in the Context of Maternal Postpartum Depression}

Maternal depression includes vegetative (e.g., changes in appetite and sleep patterns), cognitive (e.g., inattention and slowness), and psychomotor symptoms (e.g., lack of energy and interest), as well as mood swings (Cruz, Simões, \& Faisal-Cury, 2005; Frizzo \& Piccinini, 2005). Suicidal thoughts may occur and excessive guilt may also emerge. Maternal depression may occur at any time during the infant's first year of life and not necessarily during the first weeks after birth, though it is strongly associated with motherhood (Nonacs \& Cohen, 2005).

Studies focusing on fatherhood in families in which the mother experiences depression are consistent in suggesting that the participation of the father in these families is essential to emotionally supporting the mother and child (Silva \& Piccinini, 2009). These studies also show that husbands of depressive mothers are a population at the risk of having their emotional health affected and of experiencing paternal depression during the postpartum period. In this sense, we note the need for clinical interventions implemented in this context to focus not only on the depressive mother, but also include family relationships.

Additionally, considering that postpartum depression is a postpartum psychopathology, it cannot, according to Cramer and Palacio-Espasa (1993), be seen only as an intra-psychological condition, but should also be viewed as an interpersonal condition. The reason is that the psyche of father/mother and the child's psyche are indivisible during the postpartum period. There would be, therefore, a need to implement a psychotherapy modality able to deal with the specificities inherent to the postpartum period. The authors believe that the most appropriate interventions for postpartum psychopathologies like maternal depression are therapies that include the father and child. The characteristics of these therapies are a focus more on the relationship than on individuals. The shortterm psychotherapy performed by Cramer and PalacioEspasa could, according to the authors, significantly improve the infant's symptoms, interactive behaviors, and representations concerning fatherhood. The purpose of psychotherapy is not to change the parents' entire psychological functioning, but only a limited sector of investment related to the infant, which, for the authors, justifies the brevity of this technique.

In general, the number of short-term parent-infant psychotherapy sessions ranges from 4 to 12, with an average of six sessions, one per week, of approximately 60 minutes duration (Cramer \& Palacio-Espasa, 1993). The setting should simultaneously favor the parents' capacity of association and an exchange between parents and child that is free as possible, while the therapist can sometimes play with the child.
Some studies treat the impact of short-term parent-infant psychotherapy in addressing maternal depression, among other aspects of the psychological health of the mother, child and their relationship. According to Prado et al. (2009), this approach seems to be effective in promoting a better mother-father-infant relationship, and in some families, this improvement also includes the mother's depressive symptoms. Additionally, because it is an intervention performed in the infant's first moments of life, it plays a potential preventive and mental health-promoting role.

Even though Cramer and Palacio-Espasa (1993) also stress the importance of the presence of both mother and infant during short-term parent-infant psychotherapy sessions, Stern (1997) notes that the father, or an equivalent figure, needs to be factored into the treatment. According to Barrows (2003), the presence of both father and mother is essential to promoting real and lasting changes in therapies implemented together with the child, because unassimilated objects (ghosts) of the father and mother may be complementing and feeding each other.

Specifically in the context of maternal depression, Clark, Tluczek and Wenzel (2003) emphasized the importance of psychotherapy interventions to focus on the needs of the woman in performing her multiple roles (mother, woman, wife), as well as on the needs of the child and husband. Cramer and Palacio-Espasa (1993) and Stern (1997) suggest moving beyond traditional individual approaches, seeking to include the child and the father. This benefits not only the maternal functioning, but also the mother-father-infant relationship, since it can support both the father's and mother's competencies in both their parental and marital roles. In this sense, Clark et al. (2003) state that introducing the child and partner into the treatment for postpartum depression can reduce the mother's stress and support the development of the couple's competencies to perform their roles as parents and spouses, reducing the risk of recurrent depressive episodes.

The participation of fathers during treatment could also be a way to preserve their mental health, as well to enable them to deal with their wives' depression (Burke, 2003). According to Fletcher, Matthey and Marley (2006), a new infant's wellbeing requires care provided by the father as well as support provided to the mother during this new role. For that, fathers have to have emotional resources to build an effectively safe relationship with the infant. The greatest challenge in this field is to find the best way to help and encourage fathers to support their depressive wives and help them to care for the baby (Wang \& Chen, 2006).

Stern (1997), however, observed that the presence of fathers during mother-father-infant psychotherapy is very inconsistent unless their presence is a condition for the sessions to take place. In this regard, Fletcher et al. (2006) highlight that men tend to resist seeking psychological orientation or services. Roggman, Boyce, Cook and Cook (2002) verified that fathers who participate most in interventions focusing on child development have higher levels of education, are 
Silva, M. R., Prado, L. C., \& Piccinini, C. A. (2013). Father in Parent-Infant Psychotherapy.

less depressed, more religious and find it easier to seek social support. Hence, according to the authors, those who would most need to participate in interventions are less prone to do so. Therefore, the therapist should actively attempt to gain fathers' participation, based on the belief that, in addition to the fact they are benefited by the treatment, they will also make important contributions that will eventually benefit all those involved.

The reviewed literature shows that, even though the participation of fathers in clinical interventions directed to depressive mothers is widely recommended (Burke, 2003; Clark et al., 2003), they seldom attend treatment (Burke, 2003). Additionally, how this participation occurs has not been assessed. Hence, this study's objective was to investigate the participation of fathers in short-term parent-infant psychotherapy in the context of maternal postpartum depression.

\section{Method}

\section{Participants}

Two families whose mothers presented indicators of depression participated in this study. Both were married and had average-to-low socioeconomic status. The infants did not present complications either during pregnancy or birth.

Family 1 was composed of the father, Augusto, 39 years old, the mother, Marilia, 44 years old, and the infant Juliana, eight months old. All names were changed to ensure the participants' anonymity and ages refer to the first assessment meeting held with parents. The family lived in Porto Alegre, RS, Brazil and both father and mother were employed and had a bachelor's degree. The Beck Depression Inventory (BDI) indicated that Marilia presented mild depression (score of 13), which was confirmed by diagnostic interview. Augusto did not present indicators of depression, neither during diagnostic interview nor through the BDI (score of 11).

Family 2 was composed of the father, Francisco, 44 years old, by the mother Joana, 37 years old, and the infant Eduardo, seven months old. Eduardo was the couple's third child, after two daughters, one 14-year old and one 10 -year old. The family lived in the metropolitan region of Porto Alegre, RS, Brazil and only Francisco had a paid job. Both had completed high school. The BDI indicated that Joana presented moderate depression (score of 32), which was confirmed by diagnostic interview. Francisco also presented indicators of mild depression (score of 14). However, the diagnostic interview seemed not to confirm the BDI, indicating not a depressive condition, but actually a situation of high stress.

The families were part of a larger project titled: "The impact of psychotherapy on maternal depression and parentinfant interaction: A longitudinal study from the infant's birth to second year of life - PSICDEMA" (Piccinini et al., 2003) who accompanied, through psychotherapy, 22 families whose mothers presented postpartum depression. The presence of fathers was mandatory during the initial assessment and everyone was encouraged to attend the psychotherapy sessions.
The primary author of this study assisted four out of the 22 families. The first two families, whose father participated in the treatment and were cared for by the primary author, were included in this study. The first family cared for by the author was composed of only the mother and child because the father died during the pregnancy.

\section{Procedure}

Data collection. A case study design was used (Stake, 1994). Data collection followed the stages described in the project aforementioned (Piccinini et al., 2003). We list the instruments and procedures used in this study. Phase I, the initial assessment, was performed by the researcher and took place in the Interaction Process Observation Laboratory (LOPI) in the Psychological Institute at the Universidade Federal do Rio Grande do Sul (UFRGS). This is a room of two-way mirrors designed to observe family interactions. It is equipped with two video cameras and is appropriate for psychotherapy care with adults and infants, with toys and mats for babies. At this time, the mother was informed about the study's objectives and the assessment procedures to participate in the parent-infant psychotherapy. After giving their consent, the mothers signed free and informed consent forms and filled in the Initial Contact Form, which was used with the objective to select potential participants for the study. A new meeting was scheduled with the mother, father and child in order to perform the assessment. In the following meetings, the mothers and fathers individually answered the Beck Depression Inventory (Beck \& Steer, 1993). A Diagnostic Interview was conducted to either confirm or refute the presence of depression indicators. They also responded to other interviews, but the data from these are not presented in this paper (Interview addressing the couple's demographic data; Interview concerning the pregnancy and birth; Interview addressing the marital relationship; Interview addressing the experience of fatherhood; Interview addressing the experience of motherhood). Phase II of the study comprised the Shortterm Parent-Infant Psychotherapy process offered free of cost; its sessions were filmed and audio-recorded.

As previously discussed, various approaches compose the current scenario of parent-infant psychotherapies, which present a large diversity of theoretical and technical frameworks. The PSICDEMA's members opted to use mainly the psychodynamic approach of Cramer and PalacioEspasa (1993), together with the concepts of Stern (1997). This psychotherapy included 13 sessions for Family 1 and 12 sessions for Family 2. The sessions took place in the LOPI and were held by the primary author as previously reported. The sessions were weekly, supervised in groups of clinical cases attended by all the researchers participating in the PSICDEMA project. The understandings and guidance that resulted from these supervision meetings were also considered for the cases' analyses.

Data analysis. The analysis conducted in this study aimed to investigate the participation of fathers in 
parent-infant psychotherapy in the context of maternal postpartum depression. The transcriptions and videos of all the parent-infant psychotherapy sessions were used in the analysis. For that, latent content and content manifested in both the father's and mother's verbalizations and interactions were qualitatively analyzed, as were the discussions concerning the case that emerged from the supervision group. A detailed description of the analysis' procedures can be found in Silva (2007).

\section{Ethical Considerations}

The PSICDEMA study was approved by the Institutional Review Board at UFRGS (Process 200396), at the Hospital das Clinicas in Porto Alegre (Process 03-068) and at the Grupo Hospitalar Conceição (Process 88/03).

\section{Results}

The two families are presented separately through psychotherapy situations that illustrate the participation of fathers during treatment. Finally, the participation of fathers during the process of parent-infant psychotherapy is discussed in the context of maternal postpartum depression. It is worth noting that analyses were not intended to provide a dynamic understanding of the psychotherapy process or of the families attending the treatment but rather, to understand aspects related to the inclusion of fathers in the treatment. Fatherhood, or the presence of a father, was not the main focus of the psychotherapy. It mainly addressed the issue of mothers, who were the ones seeking treatment due to depressive symptoms.

\section{Family 1: Marília, Augusto and Juliana}

At the time Marilia was referred to the brief parent-infant psychotherapy, she was asked about an indication whether her husband would participate. She believed it would be positive but thought it would not be feasible because he was very resistant to the possibility of getting treatment. At the first session, Augusto was asked about his desire to participate and he in fact did not show great motivation, using his lack of time as an obstacle. It was then agreed that Augusto would attend the sessions whenever possible and he should make an effort to participate. Mother and child attended all 13 psychotherapy sessions. The father attended the first four sessions. Then he started working two jobs and became busy across three shifts, which hindered his participation. Close to the end of treatment, when Augusto started to have the nights free, I tried to schedule a session in an alternative time, to facilitate his participation, but he was not interested.

At the first psychotherapy session, Augusto showed interest in understanding Marilia's greater emotional instability, especially her greater irritability. At the time, he noted the mother's exhaustion, especially because her sleep was interrupted to breastfeed the baby during the night:
"She is more upset, more distressed at times, but I think it's because she has slept poorly."

He also showed, however, through his testimony and behavior, that he did not agree with Marilia's idea that he should be engaged in treatment to work out the couple's problems and his alcoholism. From the beginning of the session, Augusto made his resistance to participating in the short-time parentinfant psychotherapy very clear: "I came because Marilia asked me.” Sometimes he would report no need to participate, sometimes he would state he did not have time for it: "What I have to do is work (with the psychiatrist) about this anxiety so I think things will get better"; "I work so much that I think it is virtually impossible to start (psychotherapy) now.” He also resisted any possibility of treatment suggested.

Augusto's lack of interest in committing to treatment was perceived by Marilia as an attitude of indifference toward her because it showed that he did not have any intention to change. Even though she agreed, in this session, to participate in the psychotherapy even without him, she found it unfair that only she was making an effort to improve.

The difficulty of Augusto in perceiving Marilia's emotional needs and supporting her was strongly highlighted in the second session. Even though he realized she was very tired and sleeping poorly, he was not patient with the mother, noting she was too irritated and snapping at everyone around. Given Augusto's attitude, she reported feeling totally unsupported, without someone to care for her, and alone to solve all the problems: "I wanted someone who was concerned with me like this. (...) it'd be so good if I had someone that would say: 'Look, don't worry, we are together in this. We'll manage!' Marilia also related this lack of emotional support on the part of the father to his drinking: "The least he could do would be not to not drink so much.” The aspect that bothered Marilia the most was his denial of being unable to stop drinking by himself and refusal to seek help.

In regard to Augusto's participation in short-term parent-infant psychotherapy, even though he did attend this session, his resistance to continue the treatment was apparent. It made Marilia quite upset and angry.

Father: No, if she wants (the father participates in the sessions)... But I get concerned with attendance... Mother: "If she wants...” If she wants, it can’t be! Father: No, since you wanted...

Mother: You don't?

Father: No, but it makes me want it too. If you want it...(...) I want only to say that if she wants it, you know, if she wants it and if it's important to her, I can do it. Now, I'm concerned with attendance so we don't fail you (...)

Mother: Can I say something? When we want something, we make it happen. When it is a priority, it is a priority.

Father: Well, so perhaps I don't want it, you know? Mother: Perhaps you don't. That's what I've said from the beginning. 
Next session Marilia was really pleased that Augusto had not been inebriated, even once, during the day in the week between sessions. According to Marilia, what pleased her most was the effort, on the part of the father, to change, to act differently: "I was, like, waiting. Will he manage, you know? He was trying (...) I could tell he was making an effort. An attempt. (...) His desire to be better. It seemed to me.” Augusto agreed there was an effort, on his part, to act differently. He reported he tried to behave in such a way to avoid conflict with Marilia, showing he had listened to her dissatisfaction and was willing to support her.

At the fourth session, Marilia was again satisfied because Augusto had not had a drink so far. She highlighted how much this issue was crucial for her wellbeing: "When there is no alcohol, there is no argument (...) Everything is very peaceful (...) He is very fun. Living with him is very easy.” I asked Augusto again in this session about starting individual psychotherapy and he still showed no interest in treatment.

Therapist: Are you considering resuming the treatment with the psychiatrist?

Father: No, sometimes I have no desire. I feel so lazy (...)

Therapist: Augusto you have to decide how you will resume treatment (...) and you have to face the times when you're don't feel like attending the treatment.

In the fifth session, Marilia was again very dissatisfied and disappointed with Augusto because he had started to drink again: "It's, it's horrible, Gee... It’s so frustrating, you know? I figure it it's really frustrating for him too, you know? Because it must be terrible not being able to deal with it.” According to Marilia, Augusto had promised, again, to stop drinking. But she did not believe it would happen. "It's tiresome, you know? Why do I insist on it? Why insist on the same issue over and over"? She did have some hope that change would occur due to the position Augusto had assumed in his new job, which imposed a new routine on him.

At the seventh session, Marilia reported she was feeling calmer because her husband was dedicating himself to his new job and was not drinking. At the same time, she was concerned he would avoid seeking treatment to deal with this issue: "He has a hard time dealing with these issues (...) he has a hard time taking therapy seriously.” Marilia also believed he was using his job as an excuse not to participate in the psychotherapy anymore.

The issue concerning Augusto's participation in the brief parent-infant psychotherapy sessions was addressed again in the following session because the therapist had proposed to schedule a session at a time he would not be working. Marilia reported Augusto's lack of interest in any type of treatment once more, which made her feel very discouraged, not believing there was a possibility of change.
Therapist: Have you and Augusto reached on a decision (about Augusto' participation)?

Mother: Well, he's very receptive, he says yes, but doesn't say when. So, I was thinking on the way here: I'm so tired of all this! (...) 'Can it be on this Wednesday?' 'No, it can't' 'Can it be on next Wednesday?' 'No, it can't, I'll tell you later.' Then, I mention it again, and again, to the point of exhaustion and he doesn't define a date, you know? This is just an example, you know? (...) It's really tiresome. Augusto won't change. He is childish.

During the tenth session, Marilia highlighted the father's refusal to seek treatment, whether it is the parentinfant psychotherapy, a treatment with a psychiatrist or any other kind of help. At the twelfth session, Marilia said that Augusto had looked for a psychiatrist and started a drug treatment program, but she feared he would not complete the process: "I really want it to work, but I wouldn't bet on it. I really wouldn’t bet on it.” Marilia remained sad because she felt that she was always the one, in her relationship with Augusto, to provide emotional support; she had never received such support from him.

In the last session, Marilia reported her fears were confirmed: Augusto did not return to the psychiatrist, stopped taking the medication, and resumed drinking. Even though Marilia had somewhat foresaw this situation, she was very disappointed. She saw Augusto's attitude as a weakness, but also as a total disregard for her feelings, desires, and needs. His disregard, as she stressed again, was also evident in his refusal to keep participating in the short-term parent-infant psychotherapy sessions.

I guess our work here was important. I guess we saw lots of things. I guess he saw things too and ran away, you know? When you presented some things to him, he ran anyway, didn't come back. (...) When you suggested 'let's make it right' he didn't want it.

\section{Family 2: Francisco, Joana and Eduardo}

At the time Joana was referred for parent-infant psychotherapy, she was asked about the indication for her husband to attend the treatment, which she considered to be very positive. The psychotherapy was then initiated and lasted 12 sessions, over a period of five months. Mother, father and child attended all 12 psychotherapy sessions. The couple's other daughters also attended the fifth and tenth sessions.

Francisco was the one who sought treatment for the family. He also actively participated in the initial interviews and in the psychotherapy, indicating Joana's issues and also his own issues, encouraging the wife to remain in psychotherapy treatment: "She is not well, she needs treatment, I guess she's, she's sometimes kind of lost, in emotional terms.” 
In the first session, Francisco and Joana talked about how the mother was psychologically shaken in recent months and how she required the husband's support. Joana was having crying spells with a certain frequency, and in those times she would seek her husband's support, as in this situation she described:

He (baby) cried since 9am today until the time we had to come here $(6 \mathrm{pm})$. So I started crying too because I get nervous, with him all by myself, you know, and I call him (Francisco) all the time, he can't work because I get scared.

Francisco showed great motivation to participate in the psychotherapy in this first session, saying that Joana's depressive symptoms were not only her problem. On the contrary, he also felt involved, perceiving that he was not well, and therefore, also needed help:

Therapist: So, would you like to participate (in the psychotherapy)?

Father: Yes, I would.

Therapist: Good, because that was my thinking, that you could really participate (...)

Father: I guess everything is a matter of context, right? Mother, father, child, we live in the same house, we depend on the same issues, same difficulties. So, Joana's problems become mine, my problems are hers, too, and I think that if we could help each other, it is much better because, we can attend only one treatment, I guess we both need it.

Francisco played an important role during the sessions. He made an effort to understand his wife's feelings and brought to the psychotherapy important content related to the losses she was experiencing. This issue was addressed during the psychotherapy. Francisco also highlighted his concern that the psychotherapy would be effective and really help them, especially Joana, to feel better.

During the third session, Francisco showed some difficulty getting connected to his wife's emotional needs and supporting her. Francisco could more easily talk during sessions than his wife. She needed to be encouraged to talk, and required a certain time to feel relaxed and say what she was thinking. It was possible to observe in this session that Francisco "filled in" the space and did not give the time required by Joana for her to talk. Sometimes, he even interrupted her, impeding her from talking.

However, Francisco showed, as he did in the first session, himself to be concerned with the efficiency of the psychotherapy, whether it would really benefit Joana and his family as a whole. He also sought to participate actively in how the psychotherapy was being conducted, suggesting people he would like to participate in the next session and what theme should be addressed.
In the fourth session, Francisco's posture in relation to the psychotherapy was also manifested. He asked me about the need for Joana to take psychiatric medication, which had not been indicated up to that point. During the discussions about this aspect in the supervision group, the need was considered to await the indication of psychiatric assessment for some time, with a view to getting to know Joana's actual condition better, considering the discrepancies between Francisco's and her own reports about her condition. Francisco showed himself, in this session, to be more willing to listen to his wife than in the previous session, allowing her to express herself more during the session. He also showed that he was making an effort at home to be more available to her in emotional terms:

Now we have even created a custom, a rule. I leave the girls at school and go back home, because it is close, you know. I go back home, we have a cup of coffee together, talk a little about some things, and then ... I go to work.

During the sixth session, in which we more intensely discussed the difficult relationship of Joana with her mother, Francisco helped Joana to talk about this issue, relating situations they had experienced, and was also quieter, giving Joana more opportunities to talk. At the seventh session, still related to this theme, Francisco brought, at some points, a less negative view of Joana's mother: “Joana's mother has also helped us, and I guess that in the case of an extreme need, she will help us.” It was important for the psychotherapy because it helped us to see Joana's mother as a person with limitations instead of as a mean mother.

Joana, however, complained many times during the seventh session, of occasions in which Francisco did not support her emotionally, and even made her suffer. She was angry with Francisco due to his resistance to discuss, during therapy, the relationship between them and his parents. Joana was very annoyed with Francisco's attitudes in his parents' home: "Well, it was really upsetting on Saturday at your mom's place (...) Oh, I came back home even more stressed that day." She reported that Francisco's parents were very intrusive and that, even though Francisco also complained about that, he did not impose himself as the head of his family, but acted only as "son".

During the next session, Francisco was more convinced of his contribution to the type of relationship established between him and his parents, and believed he needed to establish certain limits in the relationship with his parents. The couple reported that Francisco had made an important movement toward this goal in the weekend prior to the session. But they realized there was still a long way to go. Nevertheless, Joana was pleased with her husband's effort: "Francisco made an effort, stayed with me. We even had a place to go and hang out together and everything."

At the tenth session, he again made an effort to understand situations that made his wife distressed and 
sad. He helped Joana in this session relate this sadness to the health condition of her sister, who was afflicted with a severe disease. He also believed that financial problems were making her even more distressed because they were planning a party for their older daughter's $15^{\text {th }}$ birthday: "She's kind of worried over Bianca's 15th birthday party, it's really expensive, so I guess that this overload of things to do with few resources, make her kind of tense.”

Even though he understood there were situations in Joana's life, at that time, that was affecting her mood, Francisco showed he was very concerned for his wife. He reported that she was having severe crying spells and anxiety crises again, demanding that he leave his work in a hurry to help her on another occasion. Francisco asked again about the need for psychiatric assessment and medication. Based on the reports of Francisco and Joana, and also on the discussions concerning this family held in the supervision group, I deemed it important to refer the family for a psychiatric assessment.

At the tenth session, Francisco was calmer in relation to Joana due to the interview with the psychiatrist. He continued to show his support to his wife, ensuring the family would seek the treatment prescribed. Nonetheless, he realized that Joana was brokenhearted during that week because of her sister's disease, whose condition had reached a terminal stage. Francisco showed he understood his wife's suffering and helped her to talk about it: "Joana becomes really affected by it, it comes from within, we can't control it, it comes from within.”

\section{Discussion}

The fathers who participated in this study showed very different attitudes in relation to their participation in short-term parent-infant psychotherapy. In the case of the psychotherapy implemented with Family 1, the father (Augusto) attended four of the 13 sessions, always showing a great deal of resistance to being a part of the treatment. Even though he acknowledges his need to seek treatment, he believed that his problems should be addressed in individual psychotherapy and not together with wife and daughter. In fact, the therapeutic option most appropriate for this father would be individual psychotherapy associated with medication, so he could bear alcohol abstinence. However, he would not seek treatment. Additionally, it is important to note that Augusto's alcoholism, even though it was not the cause of Marilia's emotional problems, has certainly aggravated the situation. His resistance to seeking treatment was seen by Marilia as disregard for her and emotional disconnection in relation to her.

The absence of the father in most of the sessions led to two main consequences: the wife felt overwhelmed for being the only one responsible for the family's process of change; and the therapist was hindered from more consistently addressing the father's contributions to the mother-fatherinfant relationship. In regard to this last aspect, we believed that the psychotherapy helped this father to change in terms of responsibility for financial issues because he sought a new job that ensured greater financial stability for the family, in addition to a more organized routine.

In the case of Family 2, the father (Francisco) attended all the psychotherapy sessions. We highlight his effort to encourage his wife to seek treatment and later to keep attending the psychotherapy sessions. Francisco's support of the psychotherapy was related not only related to his concerns in relation to Joana's wellbeing but also to a fear that her emotional problems, as well as his own, would affect their children.

We believe that the psychotherapy enabled some changes in relation to fatherhood in this family. At the end of the process, the father was calmer in relation to his role as father, considered himself a better, more self-assured and less impulsive father. He also felt calmer in relation to their children and more connected to their baby, frequently helping the mother to interpret the baby's communications, reassuring her.

Another change observed in this case is related to the father's representations in regard to his parents. At the end of the treatment, he was able to sometimes say "no" to his parents, giving priority to his family on certain occasions. This change had some repercussions. The first was that he started seeing his parents as less authoritative and controlling. The second was that his wife (Joana) felt more supported by her husband, who was actually assuming his role as head of the family. In this context, Barrows (1999) states that the parentinfant treatment often has the function of helping the father to become more self-assured in his paternal role. It benefits not only the father, who becomes more self-assured in relation to his capacities, but also the mother, because the father is in better condition to be a safer haven for the mother-infant dyad.

Such changes were reflected not only in the father's satisfaction and emotional health but also in the mother. This finding confirms the propositions of several authors (Clark et al., 2003; Klitzing, 2003). According to Klitzing, the understanding that the father is important from the infant's first years of life leads to the need to include fathers in parent-infant psychotherapies, both as the third object in the representations of mother and child and as a real person. Specifically in relation to maternal postpartum depression, Clark et al. (2003) state that introducing both child and partner into the treatment may reduce the mother's stress as it supports the couple's competencies in playing both the roles of parents and spouses.

The participation of the father in psychotherapy also reduced the feeling that the mother is the only one responsible for the family's process of change. Additionally, we observe that the therapist's encouragement of the father's participation in the treatment, as well as the interventions that focused on him during the process, also reduced the feeling of guilt experienced by the depressive mother in relation to her family's problems. In this context, Lamour and Letronnier (2003) state that the functioning of the father in relation to fatherhood is closely linked to the functioning of the mother and child. Therefore, the father's problems 
need to be understood and addressed, preventively or/and therapeutically, within the family context.

Some similarities were also verified in regard to the way this study's parents participated in the psychotherapy. In both cases, the father brought to the session content the mother was not able to address, or points of view different from her own, as well as additional information and descriptions of her condition in the period between sessions. The father's contributions enriched the treatment and enabled issues to be addressed during the sessions that the mother would perhaps not have expressed herself. It was essential for the treatment, considering it was a brief psychotherapy.

However, the presence of the father often inhibited the mother from addressing certain content. The mother felt more comfortable when she was alone with the child and the therapist. Additionally, in some sessions, the fathers monopolized the time expressing their points of view, their concerns and anxieties (especially in Family 2). Hence, they did not allow the opportunity to explore the mother's emotional needs during psychotherapy, giving priority to their own anxieties. At these times, it was the role of the therapist to include the mother in the session, an attitude that also had a therapeutic function for the father: the therapist served as a model, showing it was important for him to leave his inner world on some occasions, to see and listen to the mother. This element during session played an important role, which was to use the psychotherapy to display aspects of the father-mother relationship that can be addressed here and now during interaction. In some situations, however, the father left little space - including in the therapist's mind for the mother and child.

This situation was a consequence of something very characteristic of these two fathers, which was the difficulty they had, for very different reasons, to emotionally support the mothers. In Family 1, the father (Augusto) was very focused on his own problems, and could not even see, most of time, that his wife needed emotional support. In turn, the father of Family 2 (Francisco) was very concerned over his wife's problems and tried to help her, but he was as anxious as she, and could not provide her appropriate support. Both fathers were emotionally fragile, and neither was capable of welcoming and holding the mothers' anxieties, fantasies and fears. This impossibility of the fathers to emotionally support the mothers was their main complaint in relation to their husbands.

The importance of the father to provide support to the mother in the child's first months of life was emphasized by Bornholdt (2006), who considered the function of the father to be a safe haven for the mother's needs, anxieties, fantasies and desires, which regress and become exacerbated due to the characteristics inherent to the puerperium period, giving the mothers material and psychological support so that they can dedicate body and mind to the child.

\section{Final Considerations}

This study presents the analysis of only two cases, and, therefore, is not intended to make any generalizations concerning the participation of fathers in parent-infant psychotherapy. Additionally, it presented only part of two very broad clinical situations, which were only illustrated. However, an analysis of how both fathers participated in the psychotherapy enabled reflection upon the importance of fathers attending short-term parent-infant psychotherapy within the context of maternal postpartum depression. It is believed that, even though the father is usually present in parent-infant psychotherapy through the mothers' testimonies, the concrete presence of fathers during sessions enable aspects related to fatherhood to be addressed with the father, helping him to enable and provide emotional support to the mother. The participation of fathers also helped the mothers to realize they were not the only ones responsible for their families' processes of change. This was found in the family in which the father attended all the sessions (Family 2) and not in the family in which the father attended only four sessions (Family 1).

In regard to the technique, the presence of the father during sessions eases the work of the therapist because it allows her to visualize the interaction among father, mother, and child together with their difficulties, which can then be addressed "here" and "now" during the sessions (Cramer \& Palacio-Espasa, 1993). The participation of the father also helps the therapist to access a greater variety of information concerning family functioning, since the father frequently presents content not previously addressed by the mother, or exposes a different point of view. These characteristics are especially important in the case of brief treatment because they help to accelerate treatment.

It is believed, however, that the presence of the father should not be mandatory in all the sessions. It is important that the mother be respected if she does not agree to the father's participation, which, in some cases, may hamper the mother's treatment, impeding issues of her inner world being properly addressed. Additionally, this study showed that the help provided by a father during psychotherapy is strongly linked to his ability to connect emotionally with the mother. In any case, we believe that fathers should attend at least one session so that the importance of his attending further sessions could be better assessed.

\section{References}

Barrows, P. (1999). The importance of fathers in parent-infant psychotherapy. Infant Observation: The International Journal of Infant Observation and its Applications, 3(1), 74-88.

Barrows, P. (2003). Change in parent-infant psychotherapy. Journal of Child Psychotherapy, 29(3), 283-300. doi:10.1080/00754170310001625396

Beck, A. T., \& Steer, R. A. (1993). Manual for the Beck Depression Inventory. San Antonio, TX: Psychological Corporation. 
Silva, M. R., Prado, L. C., \& Piccinini, C. A. (2013). Father in Parent-Infant Psychotherapy.

Bornholdt, E. A. (2006). Inicio de la interacción padrebebé: Perspectiva histórica, política, social y académica. Unpublished doctoral thesis. Universidad del Salvador, Buenos Aires, Argentina.

Burke, L. (2003). The impact of maternal depression on familial relationships. International Review of Psychiatry, 15(3), 243-255. doi:10.1080/0954026031000136866

Cabrera, N. J., Tamis-LeMonda, C. S., Bradley, R. H., Hofferth, S., \& Lamb, M. E. (2000). Fatherhood in the twenty-first century. Child Development, 71(1), 127-136. doi:10.1111/1467-8624.00126

Clark, R., Tluczek, A., \& Wenzel, A. (2003). Psychotherapy for postpartum depression: A preliminary report. American Journal of Orthopsychiatry, 73(4), 441-454. doi:10.1037/0002-9432.73.4.441

Cramer, B. G., \& Palacio-Espasa, F. (1993). Técnicas psicoterápicas mãe/bebê: Estudos clínicos e técnicos (F. F. Settineri, Trad.). Porto Alegre: Artes Médicas.

Cruz, E. B. S., Simões, G. L., Faisal-Cury, A. (2005). Rastreamento da depressão pós-parto em mulheres atendidas pelo Programa de Saúde da Família. Revista Brasileira de Ginecologia e Obstetrícia, 27(4), 181-188. doi:10.1590/S0100-72032005000400004

Fletcher, R. J., Matthey, S., \& Marley, C. G. (2006). Addressing depression and anxiety among new fathers. Medical Journal of Australia, 185(8), 461-463.

Frizzo, G. B., \& Piccinini, C. A. (2005). Interação mãe-bebê em contexto de depressão materna: Aspectos teóricos e empíricos. Psicologia em Estudo, 10(1), 47-55. doi:10.1590/S1413-73722005000100007

Guerra, V. (2004). Cambios en la paternidad: Reflexiones sobre algunos efectos en el psiquismo del niño hoy. Revista de Psicoterapia Psicoanalítica, 6(4), 29-42.

Klitzing, K. (2003). From interaction to mental representations: Psychodynamic parent-infant therapy in a case of severe eating and sleep disorders. Journal of Child Psychotherapy, 29(3), 317-333. doi:10.1080/00754170310001625404

Lamour, M., \& Letronnier, P. (2003). Prevention of fatherhood disorders: Accompanying early father-child interaction in day-care centers. European Journal of Psychology of Education, 18(2), 191-210. doi:10.1007/BF03173484

Nonacs, R., \& Cohen, L. S. (2005). Postpartum psychiatric syndromes. In B. J. Sadock \& V. Sadock (Eds.), Kaplan \& Sadock's comprehensive textbook of psychiatry (8th ed., pp. 1276-1283). Philadelphia, PA: Lippincott Williams \& Wilkins.

Piccinini, C. A., Gonçalves, T. R., Guimarães, L. E., Silva, M. R., \& Lopes, R. S. (2013). Experiência da paternidade aos três meses do bebê. Psicologia: Reflexão e Crítica. No prelo.

Piccinini, C. A., Prado, L. C., Lopes, R. S., Schwengber, D. D., Alfaya, C. A., Frizzo, G. B., Gomes, A. G., Mayor, I. S., \& Silva, M. R. (2003). O impacto da psicoterapia para a depressão materna e para a interação pais-bebê: Estudo longitudinal do nascimento ao segundo ano de vida do bebê. Porto Alegre: Instituto de Psicologia da Universidade Federal do Rio Grande do Sul. Relatório de pesquisa não publicado.
Prado, L. C., Gomes, A. G., Frizzo, G. B., Santos, C. A., Schwengber, D. D. S., Lopes, R. S., \& Piccinini, C. A. (2009). Psicoterapia breve pais-bebê: Revisando a literatura. Revista de Psiquiatria do Rio Grande do Sul, 31(3 supl.), 1-13. doi:10.1590/S0101-81082009000400008

Roggman, L. A., Boyce, L. K., Cook, G. A., \& Cook, J. (2002). Getting dads involved: Predictors of fathers involvement in early head start and with their children. Infant Mental Health Journal, 23(1-2), 62-78. doi:10.1002/imhj.10004

Silva, M. R. (2007). Paternidade e depressão pós-parto materna no contexto de uma psicoterapia breve pais-bebê. Unpublished doctoral thesis. Universidade Federal do Rio Grande do Sul, Porto Alegre, RS.

Silva, M. R., \& Piccinini, C. A. (2007). Sentimentos sobre a paternidade e o envolvimento paterno: Um estudo qualitativo. Estudos de Psicologia (Campinas), 24(4), 561573. doi:10.1590/S0103-166X2007000400015

Silva, M. R., \& Piccinini, C. A. (2009). Paternidade no contexto da depressão pós-parto materna: Revisando a literatura. Estudos de Psicologia (Natal), 14(1), 5-12. doi:10.1590/ S1413-294X2009000100002

Silva, M. R., \& Piccinini, C. A. (2012). Paternidade: Aspectos teóricos e empíricos sobre a experiência e a prática. Manuscript submitted.

Stake, R. E. (1994). Case studies. In N. K. Denzin \& Y. S. Lincoln (Eds.), Handbook of qualitative research (pp. 236247). Thousand Oaks, CA: Sage.

Stern, D. N. (1997). A constelação da maternidade: O panorama da psicoterapia pais/bebê (M. A. V. Veronese, Trad.). Porto Alegre: Artes Médicas.

Wang, S.-Y., \& Chen, C.-H. (2006). Psychosocial health of Taiwanese postnatal husbands and wives. Journal of Psychosomatic Research, 60(3), 303-307. doi:10.1016/j.jpsychores.2005.08.012

Milena da Rosa Silva is Associate Professor, Universidade Federal do Rio Grande do Sul, Porto Alegre-RS, Brazil.

Luiz Carlos Prado is Professor, Instituto da Família de Porto Alegre, Porto Alegre-RS, Brazil.

Cesar Augusto Piccinini is Associate Professor, Universidade Federal do Rio Grande do Sul, Porto Alegre-RS, Brazil.

Received: Nov. 29 2010

$1^{\text {st }}$ Revision: Jul. $8^{\text {th }} 2011$

Approved:Apr. 11 2012

How to cite this article:

Silva, M. R., Prado, L. C., \& Piccinini, C. A. (2013). Parentinfant psychotherapy and postpartum depression: The father's participation. Paidéia (Ribeirão Preto), 23(55), 207-215. doi:10.1590/1982-43272355201308 


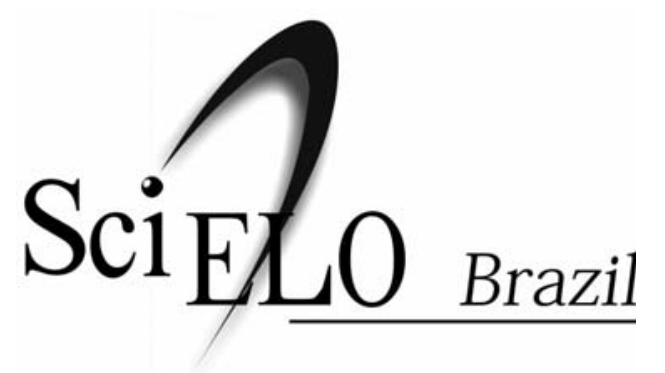

The SciELO interface provides easy access to the tables of content and to the full-text articles.

The SciELO interface also provides the retrieval of articles by the author's name, the words from title, abstract and descriptors, in addition to providing bibliometric indicators and consultation indicators.

The articles are enriched with connections to the LILACS, MEDLINE and PubMed databases.

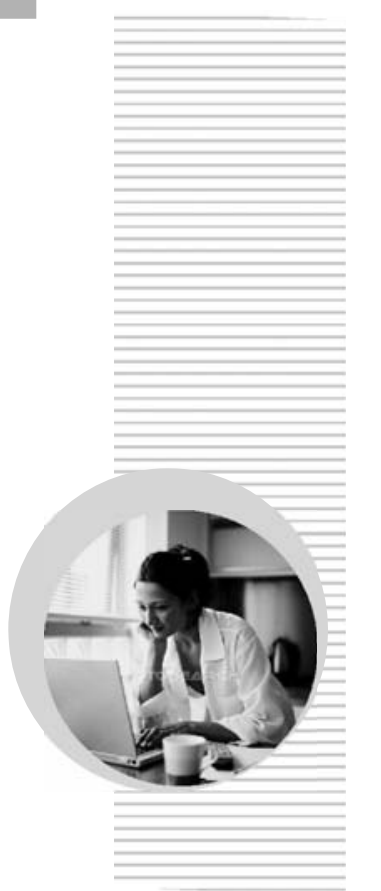

Paidéia (Ribeirão Preto) is a part of SciELO Brazil:

\section{www.scielo.br/paideia}

The SciELO interface provides access to a network of SciELO websites, gathering the major scientific journals of Latin America, Caribbean, Spain, Portugal and South Africa:

\section{www.scielo.org}

The electronic library is a project developed by the São Paulo Research Fundation (FAPESP), in partnership with the Latin American and Caribbean Center on Health Sciences Information (BIREME) and the National Council for Scientific and Technological Development (CNPq). 